\title{
Engaging Private Actors in the Production of EU Financial Regulation: Advantages and Disadvantages from a Citizen's Perspective
}

ANDREA MINTO*

\section{Introduction}

Financial regulators face chronic and severe asymmetries of information and expertise vis-a-vis regulated actors. These asymmetries are the products of, inter alia, (i) high-powered economic incentives unique to regulated actors to invest in the acquisition of information and expertise, and (ii) incomplete and often less than timely access by regulators to market- and company-specific information. ${ }^{1}$

Since the effectiveness of financial regulation depends on the ability to promptly intervene with the appropriate measures, this complexity paradigm, which entails a dynamic and proliferating risk profile, presents a fundamental dilemma for regulators. In response to this dilemma, in recent years financial regulators have sought to incorporate private regulation as a means of bridging the informational gap between the actual risk profile of regulated firms and the regulators charged with minimising the social costs incurred if those risks materialise.

New forms of collaborative and polycentric governance in fact emerged to respond better to sophisticated market failures, opening up enhanced participation and power-sharing between 'public' and 'private' actors and providing a new composite regulatory paradigm.

\footnotetext{
* Jean Monnet Professor in Law and Economics at Ca' Foscari University of Venice and Visiting Professor at the University of Southern Denmark.

${ }^{1} \mathrm{R}$ Baldwin and M Cave, Understanding Regulation: Theory, Strategy and Practice (Oxford, Oxford University Press, 1999) 126; P Mahoney, 'The Exchange as Regulator' (1997) 83 Virginia Law Review 1543; and D Awrey, 'The Dynamics of OTC Derivatives Regulation: Bridging the Public-Private Divide' (2010) 11(2) European Business Organization Law Review 155.
} 
Nonetheless, such cooperation between 'public' and 'private' raises issues pertaining to the legitimacy of regulatory power and accountability. This is particularly so in relation to third parties who might be affected by the regulatory process (financial users, depositors, consumers and citizens). A regulatory process based on the contribution of the regulated entities (financial institutions) may indeed lack legitimacy and consensus on the part of actors whose conduct might be affected by the regulatory activity.

Against such a backdrop, this chapter has two primary objectives: first, it aims to explain the growing engagement and role of non-government actors in the exercise of administrative authority; and second, it seeks to explore this trend vis-a-vis the citizen's perspective. In so doing, the chapter explains the advantages of a dynamic cooperation between public (governments, regulators) and private (regulated) parties in light of 'new governance' theory. In terms of methodology, such an approach in fact lends itself well to examining how the protection of the public interest can be best ensured by means of private regulation and enforcement. The chapter proceeds as follow: section 2 starts with charting the post-crisis institutional architecture of banking regulation and supervision in Europe and the main features of the new composite regulatory paradigm. Section 3 starts off by briefly describing the general features of the market failures with which financial regulators must cope. Then, it explains why and how innovation and modern financial intermediation have changed the style and design of regulation. It highlights the composite legal order and the different actors involved in law-making. Section 4 elaborates further upon the composite legal order of financial markets by fleshing out the different legal sources and the actors involved in the law-making process. It approaches specifically the legal arrangement and foundation, examining the exact nature of the private-public relationship. Section 5 then scrutinises the main tenets of 'new governance' scholarship and why it is particularly informative in describing the current multilevel and composite institutional architecture of banking supervision and regulation in the EU. Section 6 contends with emerging implications from a citizen's perspective. It utilises 'new governance' theory as a basis for explaining the increased involvement of private actors. The chapter ends with a forward-looking conclusion in section 7. It envisages that greater interaction between regulators, supervisors and regulated entities in banking and finance is deemed to have a number of advantages over conventional 'top-down' regulation.

\section{The Post-Crisis Institutional Architecture of Banking Regulation and Supervision in Europe}

The creation of a single financial market in Europe has, for more than half a century, had high priority on the agenda of what is now the European Union. The first initiative was the Segré Report of 1966. Initially, financial markets in Europe were 
characterised by a national orientation and approach including the use of national barriers directly or indirectly to protect national markets and market participants in each Member State. Facilitated amongst other things by a technological revolution in the financial services industry, investments and trade nowadays are global, worldwide and no longer take national boundaries into account.

In the same period, regulating financial markets and market participants has been problematic and a challenge for the European regulators. Existing laws and new regulatory initiatives have a tendency to lag behind the development in the market and have difficulties keeping up with the pace and creativity of the market and with its participants.

To overcome or at least to limit the gap between the actual market situation and the regulation, regulators have over time applied different law-making methods and instruments. In Europe, in fact, the institutional architecture of banking regulation and supervision has undergone sweeping changes in recent years. ${ }^{2}$ The 2007-08 global financial crisis (GFC) and the detrimental economic consequences that came with it unleashed an extraordinary torrent of EU institutional and regulatory reforms. Underlying much of this reform surge is a wide array of forces that illustrate how market practices, business and consumption patterns, attitudes and behaviours shook up the former institutional setting over time.

The first stage of the GFC was in fact driven by a number of factors: heterogeneous supervisory practices; global macroeconomic imbalances; waves of financial innovation; and disconnection between macro- and micro-prudential supervision. This revealed the fragility of a single market for banking and financial services built upon the pillars of 'minimum harmonization and mutual recognition.'

Such pillars sought to stimulate cross-border operations by facilitating the establishment of branches in other EU Member States, 'passporting' home EU Member State authorisations and harmonising technical standards. ${ }^{4}$ In the 1980s and early 1990s, the EU policy agenda was in fact projected to promote trust between EU Member States by underpinning the process of 'passporting' home state authorisations through minimum administrative prudential regulation and supervision for banks and investment businesses seeking to operate across borders. This architecture, however, proved outdated for sustaining the critical dimension

\footnotetext{
${ }^{2}$ See for all, the seminal contribution by C Goodhart et al, Financial Regulation: Why, How and Where Now? (New York, Routledge, 1998).

${ }^{3}$ PG Texeira, 'Europeanising Prudential Banking Supervision: Legal Foundations and Implications for European Integration' in JE Fossum and AJ Menéndez (eds), The European Union in Crises or the European Union as Crises (Arena Report Series, 2014) 527-83, 533 for a more articulate description of the various stages of the integration process and the different institutional drivers.

${ }^{4}$ In accordance with the principle of single authorisation, the decision to issue an authorisation that is valid throughout the entire European Union is the sole responsibility of the competent authorities of the home Member State. A financial institution may then provide the services, or perform the activities, for which it has been authorised, throughout the Single Market, either through the establishment of a branch or the free provision of services.
} 
and interconnections reached by the single market in the new millennium and somehow turned out to have exacerbated the detrimental effects of the crisis in Europe. ${ }^{5}$

The regulatory heterogeneity and fragmentation arising from such construction constituted a commonly identified contributor to crisis conditions. ${ }^{6}$ Not only had it opened up the use of regulatory arbitrage practices in the first place, but, once the crisis hit, it prevented policy-makers and supervisors alike from taking any appropriate action to deal with a highly intertwined and interconnected market.

As pointed out in the Larosière Report, when the crisis unfolded, it emerged that the European Union's regulatory and supervisory framework was 'fragmented along national lines despite the substantial progress achieved in financial market integration and the increased importance of cross border entities.' This in fact led up to the second phase of the crisis. The vicious spiral between the banking crisis and sovereign debts, culminating in some infamous bail-outs, ${ }^{8}$ showed the lack of an appropriate financial regulatory and supervisory architecture to keep up with modern market dynamics. The strong nexus between the credit risks of financial sectors and their sovereign states was possibly the very push needed to create a European banking union and for equipping supervisors with a harmonised set of tools to manage a banking crisis. ${ }^{9}$

To overcome these deficiencies and to foster regulatory convergence beyond minimum harmonisation, the EU overhauled the institutional structure of the European financial sector. As is well known, the institutional architecture changed significantly in response to the financial crisis and involved empowering three new EU-level agencies (the European Banking Authority, the European Securities and Markets Authority, and the European Insurance and Occupational Pensions Authority) with sectoral regulatory tasks and the creation of the European Systemic Risk Board (ESRB). In addition, the EU sovereign debt crisis gave impetus to the creation of the European Banking Union which sits on the three pillars of

\footnotetext{
${ }^{5}$ Indeed, the unheard warning that had been given ahead of the economic crisis by Tommaso Padoa-Schioppa on the inadequacy of the minimum harmonisation principle was eventually learned the hard way: a long-lasting integration of markets and a single monetary policy cannot be achieved while keeping regulation and supervision at national level (the inconsistent triad): T Padoa-Schioppa, 'How to Deal with Emerging Pan-European Financial Institutions?' (2004) speech at the Conference on Supervisory Convergence organised by Dutch Financial Minister, The Hague, available at www.ecb. europa.eu/press/key/date/2004/html/sp041103.en.html.

${ }^{6} \mathrm{~N}$ Moloney, 'EU Financial Market Regulation after the Global Financial Crisis: More Europe or More Risks' (2010) 47 Common Market Law Review 1317.

${ }^{7}$ See High-Level Group on Financial Supervision, chaired by Jaques de Larosière, Brussels, 25 February 2009.

${ }^{8}$ For a study on the mechanisms through which sovereign and bank problems feed into each other, see eg I Balteanu and A Erce 'Bank Crises and Sovereign Defaults: Exploring the Links' (2014) Banco de Espana Working Paper no 1414.

${ }^{9}$ European Parliament, 'Vicious Circles. The Interplay between Europe's Financial and Sovereign Debt Crises', Policy Briefing, June 2016.
} 
the Single Supervisory Mechanism (SSM), the Single Resolution Mechanism and the European Deposit Insurance Scheme. ${ }^{10}$

Despite Article 127.6 TFEU being the legal basis for the SSM, Article 1 SSM Regulation ${ }^{11}$ significantly and overtly emphasises that the European Central Bank (ECB) has been endowed with the 'specific tasks concerning policies relating to the prudential supervision of credit institutions, with a view to contributing to the safety and soundness of credit institutions and the stability of the financial system' (emphasis added), while ensuring the creation of a level playing field (ie having 'full regard and duty of care for the unity and integrity of the internal market based on equal treatment of credit institutions with a view to preventing regulatory arbitrage').

Such rapid expansion of the institutional infrastructure brought about new actors, powers and tools. Yet, a much more profound process of change started off along the way, affecting in certain aspects a new governance regulatory technique. Not only had the institutional design developed, but the industry itself - as a nexus of parties - had in turn confronted a structural change, ${ }^{12}$ especially in the way regulators, supervisors, financial institutions and end consumers now interact. The multilevel and composite architecture is thus accompanied - and supported by a new composite regulatory paradigm, or legal order, which is based upon a wide range of regulatory strategies, where 'external' regulation and 'internal' regulation (ie regulation produced and enforced from the outside and from the inside of regulated entities, respectively) coexist.

Traditional regulatory approaches - spanning the continuum of the rulesbased/principles- based approach - have been reshaped by increasing involvement of non-state actors. Systems of government, aimed at delivering greater efficiency and more responsive and flexible public services, brought about innovations in the organisational structures. In fact, financial regulation is coupled with rulemaking delegation ('delegification') to both administrative bodies (supervisors) and private actors (regulated entities, associations and other standard setters). This generally means that legislation is used in principle only to set the outline through general policy principles which will then be implemented and supplemented by administrative regulation and self-regulation respectively.

\footnotetext{
${ }^{10}$ See eg J Bart, 'Bail in Mechanisms in the Bank Recovery and Resolution Directive' (2014), available at https://ssrn.com/abstract=2511886 or http://dx.doi.org/10.2139/ssrn.2511886; C Veerle 'Deposit Guarantee Schemes in Europe: Is the Banking Union in Need of a Third Pillar?' [2015] European Company and Financial Law Review no 3; G Christos, 'Institutional and Legal Aspects of the European Banking Union: Status Quo and the Way Forward’ (2017), available https://ssrn.com/abstract=3093830 or http://dx.doi.org/10.2139/ssrn.3093830.

${ }^{11}$ Council Regulation (EU) No 1024/2013 of 15 October 2013 conferring specific tasks on the European Central Bank concerning policies relating to the prudential supervision of credit institutions [2013] OJ L287/63.

${ }^{12}$ What Lawrence Lessig referred to as 'architecture' - the code, protocols, platforms and structures that determine how firms, consumers and policy- and law-makers interact: L Lessig, Code (New York, Basic Books, 2006) 122.
} 
From a governance perspective, this reflects a paradigm whereby regulatory convergence is achieved by involving parties which are better positioned than politicians and regulators, both because of their superior expertise and also greater and more timely access to company-specific and market information. This chapter contends that new governance scholarship helps in getting a better understanding of the incorporation of internal private regulations into supervisory public planning.

\section{Setting the Stage for the Involvement of Private Actors: Market Failures and Complexity of Modern Financial Intermediation}

The GFC has caused profound questions to be asked about the market's ability to address severe externalities, especially those stemming from bail-outs and systemic turmoil. EU financial regulation is now routinely discussed in terms of incentives, asymmetries of information, multiple policy options, market-based instruments, quantification of benefits and costs, red-tape alerts and cost-effectiveness. In the aftermath of the crisis, in fact, EU policy-makers have rightly focused on potential solutions to the manifold conflicts of interest and regulatory lacunae that existed in the previous system. On the other hand, market failures that passed unnoticed before are now incorporated within the threats which regulators and supervisors have to cope with. ${ }^{13}$

'The design of financial regulation is thus ultimately an exercise in economics applying the analytic tools of economics to determine the legal and regulatory framework best suited to correcting the failures of financial systems. ${ }^{14}$ Economic

\footnotetext{
${ }^{13}$ According to L Snider, 'The Conundrum of Financial Regulation: Origins, Controversies, and Prospects' (2011) 7 Annual Review of Law and Social Science 121, in the age of financial liberalisation and financialisation, market-based concepts have dominated the discourse on public regulatory goals, such that regulatory goals were grounded on notions of efficiency and transaction facilitation. Following the GFC, financial regulation seems to be mainly concerned with the public good of financial stability. In spite of what appeared to be individually sound and well-supervised financial institutions, risks that were thought to be well diversified, and institutional infrastructures that appear to be robust, systemic risks nonetheless emerged, went undetected for some time and then created great havoc. Since then, through better analytical modelling, information gathering, identification, and monitoring as well as focus on macroprudential policies, systemic risk has received greater focus. On the prominence of financial stability within the goals of financial regulation (along with the advent of a macroprudential approach to safeguarding it), see eg SL Schwarcz, 'Systemic Risk' (2008) 97(1) Georgetown Law Journal ??; CJ Green, EJ Pentecost and TG Weyman-Jones, The Financial Crisis and the Regulation of Finance (Cheltenham, Edward Elgar Publishing, 2011) 101ff; SG Hanson, AK Kashyap and JC Stein, 'A Macroprudential Approach to Financial Regulation' (2011) 25(3) Journal of Economic Perspectives ??; G Galati and R Moessner, 'Macroprudential Policy - A Literature Review' (2011) BIS Working Paper no 337.

${ }^{14}$ J Armour, D Awrey, P Davies, L Enriques, JN Gordon, C Mayer and J Payne, Principles of Financial Regulation (Oxford, Oxford University Press, 2016) 51.
} 
scholarship explained this greater 'market-failure thinking' by referring to the 'public interest approach' to regulation. ${ }^{15}$ At its simplest, it is in the (EU) public economic interest to ensure the proper functioning of the internal market (in turn, instrumental to pursuing the economic goals of the Treaties) ${ }^{16}$ by overcoming or removing market failures. Particular features of financial markets make them especially prone to malfunction, failing thus to achieve the economically efficient outcomes which they are theoretically assumed to achieve. ${ }^{17}$

Market imperfections are endemic in the financial sector, due to the very factors of production that are traded and allocated between market participants: 'time', 'information' and 'risk'. Complexity of financial intermediation is thus a reflection of the conundrum of how to manage risks stemming from a great deal of uncertainty. ${ }^{18}$ The pre-eminent role in risk allocation that the financial sector carries out accentuates in turn the manifestation of market failures: asymmetric information, moral hazard, bounded rationality and negative externalities are in fact a direct function of the properties of financial markets and of the host of contrasting interests that revolve around them. Steven L Schwarcz argues that four types of market failures are inherent in the financial system - information failure, principal-agent failure, incentive failure and responsibility failure ${ }^{19}$ and shows how these market failures can eventually contribute and lead, individually or in combination, to systemic failures as the overarching economic vulnerability. ${ }^{20}$

Not only are market failures greater or more likely to come about in the financial sector, but the remedial intervention to cope with them is also extremely difficult to devise. The financial sector is therefore particularly inclined to market failures and non-market failures (or government failures) alike, as the costs of

${ }^{15}$ J Pelkmans, 'The Economics of Single Market Regulation' (2012) Bruges European Economic Policy Briefings, no 25, 13. For a comprehensive overview of economic theories of regulation, see eg J Hertog, 'Review of Economic Theories of Regulation' (2010) Tjalling C Koopmans Research Institute, Utrecht School of Economics, Utrecht University, Discussion Paper, no 18.

${ }^{16} \mathrm{On}$ market and legal integration in the European Union, see Commission Communication, 'Financial Services Action Plan: Implementing the Framework for Financial Markets' COM(1999) 232.

${ }^{17}$ JW Cioffi, 'After the Fall: Regulatory Lessons from the Global Financial Crisis' in D. Levi-Faur (ed), Handbook on the Politics of Regulation (Cheltenham, Edward Elgar, 2011) 642; I Glinavos, 'Regulation and the Role of Law in Economic Crisis' (2010) 21 European Business Law Review 539; J Benjamin, 'The Narratives of Financial Law' (2010) 30 OJLS 787.

${ }^{18}$ D Moss, When All Else Fails: Government as the Ultimate Risk Manager (Cambridge MA, Harvard University Press, 2002).

${ }^{19}$ SL Schwarcz, 'Regulating Shadows: Financial Regulation and Responsibility Failure' (2013) 70 Washington and Lee Law Review 1781. The author explains that 'responsibility failure focuses attention on the fact that the corporate reorganization provisions of bankruptcy law may protect firms, thereby motivating them to operate irresponsibly'. Nevertheless, the argument goes, 'the protection afforded by those provisions does not mean that a firm will in fact operate irresponsibly or that acting irresponsibly will necessarily result in harm to third parties'.

${ }^{20}$ SL Schwarcz, 'Controlling Financial Chaos: The Power and Limits of Law' (2012) 3 Wisconsin Law Review 816-39; SL Schwarcz, 'Regulating Shadow Banking' (2012) 31 Journal of Review of Banking \& Financial Law 619-42. 
remedying the deficiency are often greater than the benefits. ${ }^{21}$ Indeed, some of the regulatory strategies that were conceived to address and solve market failures turned out to fall short of achieving the desired outcome, or even to exacerbate the market failures. ${ }^{22}$

By the beginning of the twenty-first century, the advent of globalisation and financial liberalisation made financial markets much more vast, complex, aggressive and highly competitive. ${ }^{23}$ This period was accompanied by deregulation and a firmly held belief in the full empowerment of non-public entities involved in standard-setting, supervision and securing compliance. ${ }^{24}$

Nonetheless, the GFC exerted a profound influence on how to regulate financial markets and institutions. The pervasive belief in the social desirability of unfettered markets was in fact abandoned, since private actors - unregulated - proved to be neither rational nor fully informed so as to master risk effectively. They often pursued vested private interests in conflict with the public good and lacked any form of public accountability. Market fundamentalism therefore stopped informing public policy, and a more intrusive form of regulation gathered momentum, to account in particular for both the complexity of modern financial markets and the nature and pace of financial innovation.

Over the last decade, in fact, finance has been shifting increasingly from an industry characterised by bricks-and-mortar bank branches towards an industry

\footnotetext{
${ }^{21}$ On the fascinating area of the goals of financial regulation, and on the translation of market failures into regulatory strategies, see eg M Andenas and I Chiu, The Foundations and Future of Financial Regulation, (London, Routledge, 2014) 16ff; J Armour et al, Principles of Financial Regulation (Oxford, Oxford University Press, 2016) 61ff; LD Wall and RA Eisenbeis 'Financial Regulatory Structure and the Resolution of Conflicting Goals' (2000) Financial Modernization and Regulation 133-55; R Aspinwall, 'Conflicting Objectives in Financial Regulation' (1993) 36 Challenge 53.

${ }^{22}$ JP Trachtman, 'The International Law of Financial Crisis: Spill-Overs, Subsidiarity, Fragmentation and Cooperation' (2010) 13 Journal of International Economic Law 719.

${ }^{23}$ S Piccioto and J Haines, 'Regulating Global Financial Markets' (1999) 26 Journal of Law and Society 351; C Bradley, 'Private International Law Making for the Financial Markets' (2005) 29 Fordham International Law Journal 127; M Andenas, 'Harmonising and Regulating Financial Markets' in M Andenas and C Andersen (eds), Theory and Practice of Harmonisation (Cheltenham, Edward Elgar, 2012) 7-10.

${ }^{24}$ This phenomenon is set against the backdrop of the ideological movement from liberal political economy to neoliberalism and the predominance of economic theories of regulation. See RA Posner, Economic Analysis of Law, 7th edn (New York, Aspen, 2007); RA Posner, 'Theories of Economic Regulation' (1974) 5 Bell Journal of Economics and Management Science 335, where regulation is itself argued to be subject to the rational self-interest of participants on the supply and demand side for regulation (see also G Stigler, 'The Theory of Economic Regulation' (1971) 3 Bell Journal of Economics and Management Science 21). See also M Friedman, Capitalism and Freedom, 40th anniversary edn (Chicago, IL, University of Chicago Press, 2002). The rationality of objective behaviour underpins accepted trust and reliance in market-based solutions and governance, now commonly questioned, see J Fox, The Myth of the Rational Market (New York, HarperCollins, 2009), but warned of earlier in J Stiglitz, The Roaring Nineties (London, Penguin, 2003); A Sen, On Ethics and Economics (Oxford, Blackwell, 1987). See also A Ogus, Regulation: Legal Form and Economic Theory (Oxford, Clarendon Press, 1994). See also critical discussion in DM Driesen, 'Regulatory Reform: The New Lochnerism' (2006) 36 Environmental Law 1. A more moderate Harvard school also considers that most forms of regulation are not distorting or ineffective. See an extension of this latter school in the balanced and insightful analysis by SP Croley, Regulation and Public Interests: The Possibility of Good Regulatory Government (Princeton, NJ, Princeton University Press, 2008).
} 
composed of heterogeneous providers of services that are extended to customers via a multitude of channels and devices. Financial innovation has deeply influenced law-making, ever since it passed from being a only 'product/service changer' to a 'game changer'.

Traditionally, financial innovation has been regarded as a change in the type and variety of available financial products. ${ }^{25}$ Technological developments relating to telecommunications and data processing have spurred financial innovations that have altered bank products and services and bank production processes alike. ${ }^{26}$ A vast body of literature has studied the progress of novel financial products and scrutinised the implications that have come with such progress. One strand of economic scholarship mapped out the ability of technological improvements to increase efficiency whenever something new that reduces costs, reduces risks or provides an improved product/service is being created. ${ }^{27}$ On the other hand, the 2007-08 GFC showed that financial innovation might fall far short of attaining services that better satisfy the demands of financial system participants.

On the contrary, financial innovation could result in products designed to obscure the connected risks and which are traded in opaque dealer-intermediated markets by opaque financial institutions, ultimately making end financial consumers worse off. ${ }^{28}$ Credit default swaps, residential mortgage-backed securities and collateralised debt obligations have ignited a great deal of discussion on informational asymmetry between intermediaries and investors, agency problems and transaction costs ${ }^{29}$ as well as on the relationship between financial innovation and financial stability. ${ }^{30}$

\footnotetext{
${ }^{25}$ See, in general, E Avgouleas, 'International Credit Markets: Players, Financing Techniques, Instruments and Regulation' in H Bigdoli (ed), The Handbook of Technology Management (Willey, New Jersey, 2009) 675-92.

${ }^{26}$ AWA Boot and AV Thakor, 'Commercial Banking and Shadow Banking. The Accelerating Integration of Banks and Markets and its Implications for Regulation' in AN Berger, P Molyneux and JOS Wilson (eds), The Oxford Handbook of Banking (Oxford, Oxford University Press, 2015) 47-76.

${ }^{27}$ RC Merton, 'Financial Innovation and Economic Performance' (1992) 4(4) Journal of Applied Corporate Finance 12-22; P Tufano, 'Financial Innovation' in GM Constantinides, M Harris, and R Stulz (eds), Handbook of the Economics of Finance (Amsterdam, Elsevier, 2003) 307-35; F Allen, 'Trends in Financial Innovation and their Welfare Impact: An Overview' (2012) 18(4) European Financial Management 493-514. For a legal perspective on the subject, see eg C Brummer, 'Disruptive Technology and Securities Regulation' (2015) 84 Fordham Law Review 977.

${ }^{28}$ BJ Henderson and ND Pearson, 'The Dark Side of Financial Innovation: A Case Study of the Pricing of a Retail Financial Product' (2011) 100(2) Journal of Financial Economics 227-47 provide recent empirical analysis of a welfare-reducing financial innovation.

${ }^{29}$ 'Complexity and innovation have combined to generate significant asymmetries of information and expertise within financial markets, thereby opening the door to suboptimal contracting and exacerbating already pervasive agency cost problems': so maintains D Awrey, 'Complexity, Innovation and the Regulation of Modern Financial Markets' (2012) 2 Harvard Business Law Review 238-39. More broadly, touching upon some perverse consequences of securitisation, see N Jenkinson, A Penalver and N Vause, 'Financial Innovation: What Have We Learnt?' [2008] Bank of England Quarterly Bulletin Q3.

${ }^{30}$ See eg N Gennaioli, A Shleifer and RW Vishny, 'Neglected Risks, Financial Innovation and Financial Fragility' (2012) 104(3) Journal of Financial Economics 452-68. Some scholars argue that financial innovation correlates with increased systemic risk for the financial and economic systems. Since financial innovation involves more credit creation, such increases in leverage as a systemic phenomenon
} 
The negative economic and social consequences provoked by these sophisticated products have exerted a profound influence on how financial innovation is perceived and, perhaps most significantly, revealed the intellectual challenge of adequately accounting for both the 'good' and the 'bad' of that innovation. ${ }^{31}$

Complexity and innovation are therefore to be considered root causes of greater and more sophisticated markets failures, since they have combined to generate significant asymmetries of information, exacerbated agency costs problems and moral hazard behaviour within financial markets. Besides aggravating already pervasive market failures, they also gave rise to new issues leading up to 'too-interconnected-to-fail' situations, the full implications of which we are only just now beginning to understand.

To keep up with such fluid and dynamic market practices, the EU regulatory framework evolved along two trajectories. On one side, a comprehensive and detailed new set of harmonised provisions has been produced, both at level 1 (Directives and Regulations) and level 2 (implementing measures released by the European Supervisory Authorities). On the other side, ad hoc venues for selfregulation have been opened up, as a way to better adapt to the rash developments occurring in the financial markets and so to respond properly to the intensified potential market failures and negative externalities. ${ }^{32}$ The 'command-and-control rules-based and principles-based techniques have thus been enriched by selfregulation, consisting of self-imposed or self-enforced rules. ${ }^{33}$ In that respect, Marco Lamandini and David Ramos Muñoz have taken the view that external regulation and self-regulation have become intertwined and mutually reinforcing, up to the point that they are 'bound to co-exist': 'This would make self-regulation an "add on" in respect to external regulation and it would be capable of bringing about additional gains in social welfare, which would not be made, however, compulsory by external regulation. ${ }^{34}$

often create greater risk for all participants and could raise systemic fragility in the face of shocks or crises: T Adam and A Guetter, 'Pitfalls and Perils of Financial Innovation: The Use of CDS by Corporate Bond Funds' (2015) 55 Journal of Banking and Finance 204; T Yorulmazer, 'Has Financial Innovation Made the World Riskier?, CDS, Regulatory Arbitrage and Systemic Risk' (2013) Federal Reserve Bank of New York paper, available at: https://ssrn.com/abstract=2176493.

${ }^{31}$ T Beck, T Chen, C Lin and FM Song, 'Financial Innovation: The Bright and the Dark Sides' (2014) 72 Journal of Banking \& Finance 28-51.

${ }^{32}$ K Alexander and N Moloney, Law Reform and Financial Markets, Elgar Law Series (Cheltenham, Edward Elgar, 2011) vii (Introduction).

${ }^{33}$ F Cafaggi, 'Rethinking Private Regulation in the European Regulatory Space' (2006) 22, available at: https://papers.ssrn.com/sol3/papers.cfm?abstract_id=910870, classified self-regulation in the following categories as: (i) mandated private regulation, where an industry is required or designated by the government to formulate and enforce norms within a framework set by the government; (ii) sanctioned private regulation, in which a private body formulates the norms which are then subjected to governmental approval; (iii) coerced private regulation, where the industry formulates the norms in response to threats by the government that if the industry does not, the government will impose statutory regulation; (iv) voluntary private regulation, where there is no active state involvement.

${ }^{34}$ M Lamandini and DR Muñoz, EU Financial Law (Cedam, Padova, 2016), 102. On the same lines, D Awrey, 'Regulating Financial Innovation: A More Principles-Based Alternative?' (2010) 5(2) Brooklyn Journal of Corporate, Financial and Commercial Law 273; refers to "de-centered" understanding of regulation which spans the public-private divide to encompass all forms of social control or influence whether generated, monitored and enforced via the apparatus of the state or other sources'. 


\section{On the Interplay between Public and Private Modes of Regulation: Legal Arrangement and Foundation of the Private-Public Relationship}

Although the GFC has led to a resurgence of public regulatory power, no amount of re-regulation could ever elevate the state to a position of substitute for the variety of actors in governance that have arisen, nor is that an ideal position from either a practical or normative point of view. ${ }^{35}$

Thus, the financial sector situates itself in a multilevel or 'decentred' regulatory space, ${ }^{36}$ which is indeed the result of complexity, fragmentation, interdependencies, ungovernability and the rejection of a clear private-public distinction. ${ }^{37}$ The EU financial regulatory framework extends to a wide array of 'regulatory tools' which encompass external regulation, recommendations and guidelines as well as self-regulation/internal regulation. The decentred analysis acknowledges that the financial services industry is a powerful and innovative industry that has been able to exert self-governance over many of its activities, if properly empowered and supervised. ${ }^{38}$ In recent years regulators have in fact been actively encouraging the financial sector to take the leadership in developing forms of reflexive regulation to govern the sector's activity, emphasising recourse to market-based solutions instead of the sometimes inappropriate hand of regulation. ${ }^{39}$ However, contrary to deregulation practices, in the current regulatory space regulators arguably remain entrusted with the powers to protect and take care of 'public interest' or 'public good. ${ }^{40}$ The 'public' character of regulators in the regulatory space is arguably distinct and this is conceptually sustainable even if the regulatory space is decentred.

\footnotetext{
${ }^{35} \mathrm{H}$ Wilke Governance in a Disenchanted World (Cheltenham, Edward Elgar, 2009).

${ }^{36}$ J Black, 'Critical Reflections on Regulation' (2002) 27 Australian Journal of Legal Philosophy 1.

${ }^{37}$ Black indeed argues that decentred regulation is premised on these five preconditions. 'Complexity' refers to the nature of problems that may need to be dealt with. 'Fragmentation' refers to the fragmentation of knowledge, resources and capacity for control in the regulatory space. 'Interdependencies' refers to the dynamics between the participants in the regulatory space, coproducing and co-enforcing norms of governance. 'Ungovernability' refers to the autonomy and unpredictability of actor behaviour in the regulatory space, which will pose challenges to assumptions made by regulatory authorities. In a decentred landscape, there is, some argue, no public-private distinction as all participants contribute to and influence governance.

${ }^{38}$ J Black, 'Enrolling Actors in Regulatory Systems: Examples from UK Financial Services Regulation' [2003] Public Law 63; J Black, 'Mapping the Contours of Contemporary Financial Services Regulation' (2002) 2 Journal of Corporate Law Studies 253. For a concurring account from the sociological point of view, see also L Snider, 'The Conundrum of Financial Regulation: Origins, Controversies, and Prospects' (2011) 7 Annual Review of Law and Social Science 121.

${ }^{39}$ S Pagliari, 'Who Governs Finance? The Shifting Public-Private Divide in the Regulation of Derivatives, Rating Agencies and Hedge Funds' (2012) 18 European Law Journal 44.

${ }^{40}$ GRD Underhill, 'Theorizing Governance in a Global Financial System' in P Mooschlechner, H Schuberth and B Weber (eds), The Political Economy of Financial Market Regulation (Cheltenham, Edward Elgar, 2006) 4; RP Malloy, Law in a Market Context (Cambridge, Cambridge University Press, 2004) 122ff.
} 
More broadly, the regulatory landscape in the EU financial sector has become a composite legal order which comprises many sets of rules at different levels, and a diversified range of actors engaged in producing them. Such a new legal order has been depicted as a policy and regulatory 'circle', or 'wheel', as contrasted with the hierarchical pyramid. ${ }^{41}$ Unlike the pyramidal structure, the wheel accounts for the current multilevel institutional setting and the multiplicity of public and private actors implicated in the process of financial regulation. It illustrates the coexistence of global and local, and public and private actors, with a variety of sources and a variety of modes of regulation. Hard law relies extensively on soft law, and leaves appropriate room for self-regulation. Governance and markets tend to be tangled with each other, and so do the parties involved in drafting and developing the regulatory framework ${ }^{42}$ Elaborating upon the 'regulatory wheel' developed by Marco Lamandini ${ }^{43}$ such mutual reinforcing interaction between international standard setters, law-makers, supervisors and private actors can be graphically sketched out as shown in Figure 8.1.

Figure 8.1 Interaction between legal sources

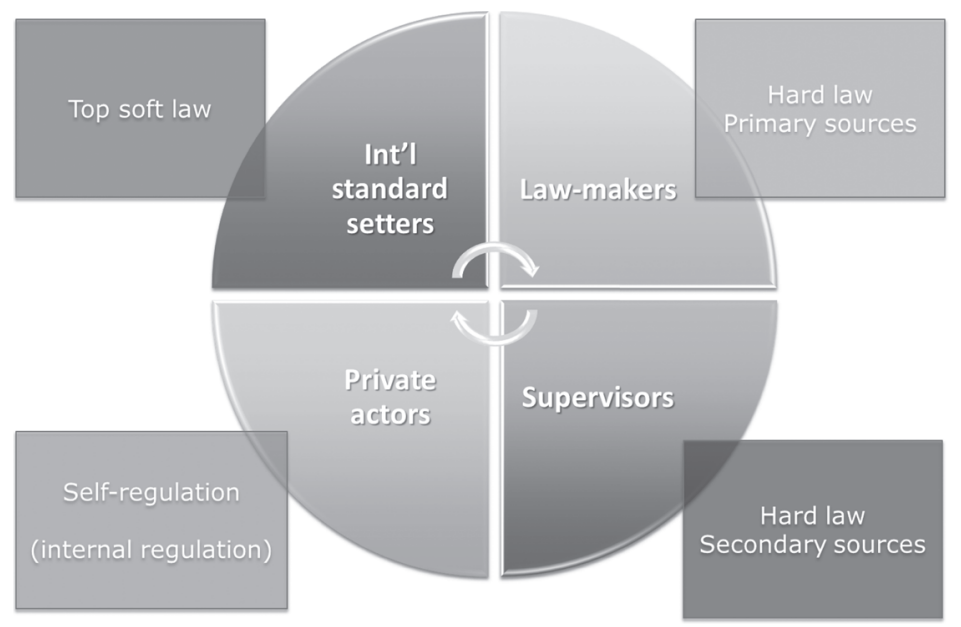

\footnotetext{
${ }^{41}$ I Ayres and J Braithwaite, Responsive Regulation: Transcending the Deregulation Debate (New York, Oxford University Press, 1992); J Braithwaite, 'The Essence of Responsive Regulation' (2011) 44(3) UBC Law Review 475-520; S Cassese, 'La nuova architettura finanziaria europea, in Dal testo unico bancario all'Unione bancaria: tecniche normative e allocazione dei poteri' [2014] Quaderni di ricerca giuridica della Consulenza Legale della Banca d'Italia 19; M Lamandini and D Ramos Munoz, A Simplified Model for European Capital Markets' Law (Bologna, Libreria Bonomo, 2014) 97ff; C Arup, 'The Global Financial Crisis: Learning from Regulatory and Governance Studies' (2010) 32 Law and Policy 363 refers to this as the matrix of state and corporate power in co-governing the financial sector.

${ }^{42} \mathrm{C}$ Brummer, 'How International Financial Law Works (and How it Doesn't)' [2011] Georgetown Law Journal 11-15.

${ }^{43}$ M Lamandini, 'Il diritto bancario dell'Unione, in Scritti sull'Unione Bancaria' [2016] Quaderni di ricerca giuridica della Banca d'Italia 81 .
} 
The decentred landscape is dominated by state-based regulators alongside international bodies and standard-setters (such as the Bank for International Settlements, the International Organization of Securities Commissions, the International Monetary Fund and the Financial Stability Board) and private financial services industry participants and national competent authorities. This is thus reflected in the coexistence of hard and soft law, which equally contribute to moulding the legal space, in a sort of 'participative style of management. ${ }^{4}$

Figure 8.1 is divided into quadrants that can be read both in top-down and bottom-up perspective. In top and bottom left, respectively, are the soft law of international sources, mainly the expression of non-conventional types of international institutions and without any legally binding effects and the soft law produced by market participants. In the other two quadrants are the prescriptive legislative sources of supranational federal, state and prescriptive rules released and implemented by supervisors. In the financial sector soft law provisions can become de facto compulsory for both public institutions and private market players. ${ }^{45}$ Such a situation occurs, for instance, when a supervisory authority considers selfregulatory best practices as a decisive factor in assessing a financial institution's compliance with general principles of supervision such as safety and soundness, fairness or transparency. ${ }^{46}$

Rule-making is a dynamic process whereby rules move frequently from one quadrant to another, enriching the content and adding to it at each transition. Such a paradigm is premised on the idea that the regulatory space should be composed of 'knowledge-based' actors. Hence, the regulated industry is likely to maintain a position of 'authority' in governance in the post-crisis landscape, by virtue of the set of information it possesses. The regulatory wheel could be said to be dominated by knowledge-based individuals and communities whose collective role provides a form of governance that is perceived as legitimate and credible because of the knowledge base, professionalism and rationality found in operation and action. Hence they are likely to have the authority to participate in governance. ${ }^{47}$

\footnotetext{
${ }^{44} \mathrm{C}$ Coglianese and D Lazer 'Management-Based Regulation: Prescribing Private Management to Achieve Public Goals' (2003) 37 Law and Society Review 691-730.

${ }^{45}$ In this respect, the ECJ recently held that guidelines or recommendations issued by the ECB to national competent authorities (NCAs) can be considered as having a legal effect whenever the NCAs feel somehow obliged to abide by these guidelines and recommendations; or, to put it another way, if such is 'the perception of the Policy Framework on the part of the euro area Member States' regulatory authorities'. See Judgment of the General Court, T-496/11, 4 March 2015, United Kingdom v ECB, para 42.

${ }^{46}$ The former materialises in situations like the one so neatly described by Art 6 of Directive 2013/36/UE where it reads: 'Member States shall ensure that the competent authorities make every effort to comply with those guidelines and recommendations issued by EBA in accordance with Article 16 of Regulation (EU) No 1093/2010 and to respond to the warnings and recommendations issued by the ESRB pursuant to Article 16 of Regulation (EU) No 1092/2010'.

${ }^{47}$ GS Drori and JW Meyer, 'Global Scientization: An Expanded Environment for Organization' in GS Drori, JW Meyer and H Hwang (eds), Globalization and Organization (Oxford, Oxford University Press, 2009) 50; GS Drori, ‘Governed by Governance’ in Drori, Meyer and Hwang, ibid, 91.
} 


\section{What is the Role for Private Regulation in Achieving Social and Economic Goals Relating to the Banking Industry?}

Ensuring effective EU financial regulation in overcoming market failures (including excessive fragmentation of the internal market as such) is not only a function of the risks involved, ${ }^{48}$ but also of the information and engagement that each market player can provide. Even when risks are high, and so are the potential market failures to be overcome, EU banking law seems to favour a flexible regime of co-regulation, which foresees the engagement of a variety of parties. This regime consists of relatively 'light' substantive rules - primarily about the regulatory objectives, complemented by some common principles, the layers of conformity assessment when using EU standards and some administrative arrangements plus a safeguard clause - complemented (and influenced) by private initiatives. ${ }^{49}$

The approach hinges on a regulatory framework that is not excessively prescriptive and which sets out certain objectives to be obtained. Such a regulatory strategy has recently been referred to as 'meta regulation', in that regulators provide a broad framework which allows regulated entities to implement systems and processes to achieve the regulatory objectives. ${ }^{50}$

Looking at the financial legal order, Talbot maintained that 'principles-based regulation, meta regulation, risk-based regulation, reflexive regulation and gatekeeper regulation all apply, in an attempt to deliver a cooperative private-public rule making and supervisory environment. ${ }^{51}$ This in turn implies the involvement of multiple actors along the different stages of the law-making process (legislation, rule-making, implementation and enforcement). In so doing, policy-making

${ }^{48}$ J Pelkmans, 'The Economics of Single Market Regulation' (2012) Bruges European Economic Policy Briefings 25, 13.

${ }^{49}$ S Omarova and A Feibelman, 'Risks, Rules, and Institutions: A Process for Reforming Financial Regulation' (2009) 39 University of Memphis Law Review 881, 920; MH Baer, 'Governing Corporate Compliance' (2009) 50 Boston College Law Review 952-54.

${ }^{50} \mathrm{C}$ Coglianese and E Mendelson, Meta-Regulation and Self-Regulation' in R Baldwin, M Cave and M Lodge (eds), The Oxford Handbook of Regulation (Oxford, Oxford University Press, 2010); J Wright, P Dempster, L Keen, P Allen and A Hutchings, 'The New Governance Arrangements for NHS Foundations Trust Hospitals: Reframing Governors as Meta Regulators' (2012) 90 Public Administration 351; C Parker, 'Meta-Regulation: Legal Accountability for Corporate Social Responsibility' in D McBarnet, A Voiculescu and T Campbell (eds), The New Corporate Accountability: Corporate Social Responsibility and the Law (Oxford, Oxford University Press, 2007); C Scott, 'Regulating Everything: From Mega- to Meta-Regulation' (2012) 60 Administration 61ff.

${ }^{51}$ L Talbot, Progressive Corporate Governance for the 21st Century (London, Routledge, 2013) 148ff, where there is also the complementing observation that 'meta regulation is a form of enforced selfregulation ... and involves the regulator delegating authority to the regulated to design its own standard setting and mode of compliance, which is overseen by the regulator' (151); reflexive regulation implies in turn that 'those regulating the self-regulation of others may subsequently have their role concretised in law and give statutory authority' (152) and gatekeeping regulation 'involves a focus and engagement with those who are not regulators themselves but have a strategic position over those who are, which enables them to exercise influence or control over them' (152). 
evolved from a centralised 'top-down' ordering process, to a 'decentralised', multilevel process, well described as a 'process of mutual problem-solving among stakeholders from government and the private sector. ${ }^{5}$

Such a 'decentring governance' tendency is reflected in the main tenets of new governance theory, which provides theoretical support for increased reliance on self-regulation and shared governance roles in the financial industry sector. Such co-governance models are based on the principle of 'co-opting the industry to govern itself, ${ }^{53}$ insofar as this is necessary to achieve regulatory objectives.

Sociolegal scholars have in fact contributed to a rich 'new governance' literature regarding the evolving methodologies and tools of governance. ${ }^{54}$ The central principle of 'new governance' literature posits that traditional 'command-and-control', 'top-down', regulation has been replaced by or integrated with, to varying degrees, new forms of collaborative governance which emphasise a dynamic cooperation between public (governments, regulators) and private (regulated) parties. Such a view is in stark contrast with that of public choice theorists, who typically frame private involvement as a threat to a proper administrative process, emphasising the risks of strategic manipulation and describing policy choices as a product of pressure on the part of well-organised and powerful private actors. ${ }^{55}$

'New governance' theory conceptualises that regulatory effectiveness and enforcement depend on the tools through which governance is effectuated, focusing therefore on the regulator-regulatee mode of interaction. It is thus a strategy that can coexist with traditional administrative activity as a complementary tool to respond to the increasing complexity of modern forms of social organisations. ${ }^{56}$ 'New governance' refers to a wide range of administrative governance regulatory techniques and tools that all share some defining features: increased participation

\footnotetext{
${ }^{52} \mathrm{~J}$ Scott and DM Trubek, 'Mind the Gap: Law and New Approaches to Governance in the European Union' 8(1) (2002) European Law Journal 5.

${ }^{53} \mathrm{M}$ Andenas and IH-Y Chiu, The Foundations and Future of Financial Regulation: Governance for responsibility (London, Routledge, 2013) 84.

${ }^{54}$ Among the main contributions pertaining to new governance scholarship, see: EF Gerding, 'Code, Crash, and Open Source: The Outsourcing of Financial Regulation to Risk Models and the Global Financial Crisis' (2009) 84 Washington Law Review 127; Lester M. Salamon, The New Governance and the Tools of Public Action: An Introduction, 28 FordhamUrb. L.J. 1611 (2001).; A and O Lobel, 'Stumble, Predict, Nudge: How Behavioural Economics Informs Law and Policy' (2009) 108 Columbia Law Review 2098-2132; O Lobel, 'Setting the Agenda for New Governance Research' (2004) 89 Minnesota Law Review 498-502; with specific regard to the application of new governance theory to financial regulatory reform, see eg R Weber, 'New Governance, Financial Regulation and Challenges to Legitimacy: The Example of the Internal Models Approach to Capital Adequacy Regulation' (2010) 62 Administrative Law Review 783-870.

${ }^{55}$ See S Ackerman, 'Progressive Law and Economics - And the New Administrative Law' (1988) 98 Yale Law Journal 344-47; WN Eskridge, 'Implications of Public Choice Theory for Statutory Interpretation' (1988) 74 Vanderbilt Law Review 285; GS Becker, 'A Theory of Competition Among Pressure Groups for Political Influence' (1983) 98 Quarterly Journal of Economics 371.

${ }^{56}$ Trubek, David M. and Trubek, Louise G., New Governance \& Legal Regulation: Complementarity, Rivalry, and Transformation. Columbia Journal of European Law, Summer 2007; Univ. of Wisconsin Legal Studies Research Paper No. 1047. Available at SSRN: https://ssrn.com/abstract=988065 539-42.
} 
of, and power sharing with, private actors; public adoption of rules negotiated by non-state stakeholders; promotion of competition and diversity as a structural component of regulation; dynamic, responsive and dialogic law-making processes as a response to dynamic regulated markets; composite and multilevel legal ordering; and the use of broad legal frameworks integrated by flexible, revisable rules and standards. ${ }^{57}$

The common thread of all 'new governance' initiatives is thus the deployment of innovative modes of interaction and techniques to overcome intractable market failures which are not solvable by adopting a traditional command-and-control regulatory model alone. In that respect, legal scholarship has identified three main characteristics as being the most relevant to regulatory reforms in dynamic and complex financial markets: (i) retention of a public role in law-making and enforcement; (ii) active pursuit of private actors' knowledge as a supplement; and (iii) a dynamic, flexible and dialogic law-making process. ${ }^{58}$

Most of the debate on style and approaches of regulation focuses on the dialectic between principles- and rules-based approaches (often simplistically referred to as a 'trade-off'). At its simplest, a principles-based approach sets out general objectives to be achieved while leaving the choice of form and methods for achieving these objectives to firms. A rules-based regulatory regime, by contrast, prescribes detailed individual rules, laying down the precise conduct that firms are required to adopt and perform.

The principles-rules tension represents one of the most enduring dialectics in legal thought in terms of determining the optimal legal strategy to achieve regulatory goals. ${ }^{59}$ In that respect, legal and economic scholars alike have attempted to differentiate between rules and principles on the basis of, inter alia, their general or specific style,${ }^{60}$ their temporal orientation, ${ }^{61}$ the degree of discretion they confer upon regulated actors, ${ }^{62}$ and the position they occupy within the hierarchy of norms. ${ }^{63}$ The largely binary nature of this debate (ie 'trade-off') is likely to misrepresent that, in reality, rules and principles are simply the 'endpoints of a spectrum.' ${ }^{64}$

\footnotetext{
${ }^{57}$ For a precise list of attributes, see R Weber, 'New Governance, Financial Regulation and Challenges to Legitimacy: The Example of the Internal Models Approach to Capital Adequacy Regulation' (2010) 62 Administrative Law Review 783. The author warns that no new governance tool draws on all these characteristics.

${ }^{58}$ ibid, 783-870.

${ }^{59}$ See eg Awrey (n 1) 273-315.

${ }^{60}$ LA Cunningham, 'A Prescription to Retire the Rhetoric of "Principles-Based Systems" in Corporate Law, Securities Regulation, and Accounting' (2007) 60 Vanderbilt Law Review 1411, 1419.

${ }^{61}$ L Kaplow, 'Rules versus Standards: An Economic Analysis' (1992) 42 Duke Law Journal 557, 565-67; F Schauer, 'The Tyranny of Choice and the Rulification of Standards' (2005) 14 Journal Contemporary Legal Issues 803, 803-04;

${ }^{62} \mathrm{M}$ Nelson, 'Behavioral Evidence on the Effects of Principles- and Rules-Based Standards' (2003) 17 Accounting Review 91.

${ }^{63}$ C Sunstein, 'Problems with Rules' (1995) 83(4) California Law Review 953, 966.

${ }^{64}$ R Korobkin, 'Behavioral Analysis and Legal Form: Rules vs Standards Revisited' (2000) 79 Oregon Law Review 23, 26.
} 
However, endpoints are still commonly adopted - despite the simplification - to describe the advantages and disadvantages of the two extreme approaches and then to set a hybrid regulatory response accordingly. ${ }^{65}$

Recently, the dialectic of rules versus principles has been pushed forward and recast in terms of the 'transaction and social costs stemming from 1) the generation of legal norms, 2) their subsequent application by decision-makers, and 3) the resulting incentive effects on those subject to their application. ${ }^{66}$ If we take this perspective, the generation of detailed rules will typically result in greater ex ante transaction costs attributable to the time and effort expended by drafters in order to articulate the empirical substance of triggers and to match these triggers with the appropriate legal response. ${ }^{67}$

When regulating dynamic and complex market behaviour, though, traditional 'rule-principle polarity thinking' ends up producing either over- or underinclusive rules, failing thus to achieve the regulatory objectives. ${ }^{68}$ Worse still, it might result in unexpected consequences which contribute to exacerbating market complexity, and eventually igniting market failures. Either way, an ex ante rule or principle is very unlikely to be construed so as to keep up with the dynamism of modern financial intermediation. ${ }^{69}$ In that respect, Christie Ford notes that a highly complex and dynamic scenario, especially as characterised by regulatorregulatee information gaps, is susceptible to neither rules (due to the information asymmetries) nor principles (because of the incapacity of capturing frequently occurring transaction events), but more likely an intermediate juncture between the two.

New governance scholarship gets around such theoretical dilemmas by focusing on the way in which the regulatory tools (whether they consist of rules or

\footnotetext{
${ }^{65}$ A rules-based approach aims to increase certainty and predictability, for regulators and regulated entities alike. For the former, it ensures having set a clear objective to be achieved, for the latter it is easier to estimate the compliance costs. Alternatively, principles-based regulation moves from a directing relationship of telling and doing between regulators and regulatees to a relationship in which regulators communicate their goals and expectations, and regulatees are entrusted with the responsibility to adopt processes and practices that ensure that these goals are substantively met. For a synthesis, see the landmark contributions of Julia Black, where there are also further references: J Black, 'The Rise, Fall and Fate of Principles-Based Regulation' in K Alexander and N Moloney (eds), Law Reform and Financial Markets (Cheltenham, Elgar Financial Law Series, 2011) 3. For a detailed account of risk-based regulation, see also J Black, 'The Development of Risk-Based Regulation in Financial Services: Just Modelling Through?' in J Black, M Lodge and M Thatcher (eds), Regulatory Innovation, A Comparative Analysis (Cheltenham, Edward Elgar, 2005) 156; J Black, 'Regulatory Styles and Supervisory Strategies' in N Moloney, E Ferran and J Payne (eds), The Oxford Handbook of Financial Regulation (Oxford, Oxford University Press, 2015) 218 (offering a comprehensive and insightful review of regulatory styles).

${ }^{66}$ Awrey (n 1) 273-315.

${ }^{67}$ RB Korobkin, 'Behavioral Analysis and Legal Form: Rules vs Standards Revisited' (2000) 79 Oregon Law Review 23, 26.

${ }^{68}$ For some evidence in the wake of the financial crisis, see eg C Ford, 'Principles-Based Securities Regulation in the Wake of the Global Financial Crisis' (2010) 55 McGill Law Journal 257.

${ }^{69}$ LA Cunningham, 'A Prescription to Retire the Rhetoric of "Principles-Based Systems" in Corporate Law, Securities Regulation, and Accounting' (2007) 60 Vanderbilt Law Review 1481-91, stresses the 'temporal division between rules, the content of which is set out ex ante, and principles, the content of which is filled in ex post'.
} 
principles) are designed to achieve the objectives in a decentralised and dynamic marketplace. From a new governance perspective, therefore, principles- or rulesbased regulatory techniques are to be studied as components of flexible legal systems which are open to diverse forms of articulation. Regulatory effectiveness and enforcement is to be sought by focusing on the regulator-regulatee mode of interaction and the tools through which governance is effectuated.

Standing in contrast to the traditional legal-centric paradigm, financial regulation is premised upon an iterative, dialogic, ${ }^{70}$ relationship within which regulated actors are invited to play a potentially important role within the process of generating regulation. An internal ratings-based approach (IRB) and an internal control system are clear examples of forms of private-public regulation. ${ }^{71}$

On the one hand, Robert F Weber convincingly demonstrates how regulators adopted the internal models approach as a means of more closely calibrating capital requirements to the actual risk profiles of banks, which had become increasingly complex over time. He approaches capital adequacy regulation by applying the new governance theory as an analytical framework. He advocates new modes of interaction between public and private actors in overcoming the flaws stemming from a solely 'top-down' prescriptive risk-weighting approach. ${ }^{72}$

On the other hand, Iris H-Y Chiu puts forwards strong arguments in favour of a regulatory approach that empowers and enhances the capacity of financial institutions to self-regulate ('meta regulation') their internal governance measures. This is a form of delegated governance by regulators to banks, and banks can have considerable discretion in designing the implementation systems and processes. As she maintained,

regulatory interest in the institution of internal control at banks and financial institutions lies in its organisational position and role. Internal control has proximity to inside knowledge and issues, and acts as an internal gatekeeper for banks and financial institutions. It may be argued that such an organisational position and role could also serve the regulator's objective of securing the financial institution's compliance with regulatory requirements. In other words, internal control is increasingly being fashioned as an internal gatekeeper which serves gatekeeping purposes for the regulator. ${ }^{73}$

Such a hybrid nature resembles the distinction made by Dan Awrey between the 'substantive' and 'technological' content of principles-based regulatory measures.

\footnotetext{
${ }^{70}$ J Black, Rules and Regulators (Oxford: Clarendon Press, 1997) 37.

${ }^{71}$ Awrey (n 1) 18.

${ }^{72} \mathrm{R}$ Weber, 'New Governance, Financial Regulation and Challenges to Legitimacy: The Example of the Internal Models Approach to Capital Adequacy Regulation' (2010) 62 Administrative Law Review 784-840.

${ }^{73} \mathrm{IH}-\mathrm{Y}$ Chiu, Regulating (From) the Inside: The Legal Framework for Internal Control in Banks and Financial Institutions (Oxford, Hart Publishing, 2015) 3-34.
} 
The substantive content of a principle is collectively made up of the animating principle itself (eg 'a firm must conduct its business with integrity'), the statutory construction of any norms giving effect to this principle (eg anti-fraud provisions), the interpretive assumptions underpinning this statutory construction (eg the common law definition of fraud) and, importantly, the desired regulatory outcomes (eg the promotion of confidence in financial institutions and markets). The technological content of a principle, on the other hand, consists of the policies and procedures implemented by regulated actors for the purpose of achieving desired regulatory outcomes.

The same paradigm holds true for recovery and resolution. ${ }^{74}$ Indeed, recovery and resolution planning envisages that the responsibility for articulating the general outline (or 'substantive content of principles') resides with regulators, whereas the internal procedures ('technological content') are conceived to be generated by the regulated actors. Furthermore, such a mode of interaction contemplates that regulators will leverage the information and expertise of regulated actors when generating and updating substantive content. ${ }^{75}$

However, non-government actors are involved in all stages of the regulatory and administrative process, sometimes assuming or sharing roles that we think either are, or ought to be, reserved for public actors. Such a cooperation between 'public' and 'private' raises issues pertaining to the legitimacy of regulatory power. This is particularly so in relation to third parties who might be affected by the regulatory process (financial users, depositors, consumers, citizens). A regulatory process based on the contribution of the regulated entities (financial institutions) may indeed lack legitimacy and consensus on the part of those whose conduct might be affected by the regulatory activity (eg depositors).

In fact, many private actors participate in governance in ways that are rarely recognised by the public, acknowledged by politicians or carefully analysed by legal scholars. ${ }^{76}$

\footnotetext{
${ }^{74}$ See A Minto, 'Banking Crisis Management, Recovery and Resolution Planning, and "New Governance" Theory: Approaching "Living Wills" as a Public-Private Collaborative Form of Regulation' [2018] European Company and Financial Law Review 4.

${ }^{75}$ See C Coglianese, and D Lazer, 'Management-Based Regulation: Prescribing Private Management to Achieve Public Goals' (2003) 37 Law and Society Review 691-730, in which the authors analysed a regulatory approach that they call 'management-based regulation'. Management-based regulation directs regulated organisations to engage in a planning process that aims towards the achievement of public goals, offering firms flexibility in how they achieve these goals. Management-based regulation can be an effective strategy when regulated entities are heterogeneous and regulatory outputs are relatively difficult to monitor. However, it requires a far more complex intertwining of public and private sectors than is typical of other forms of regulation, owing to the regulators' need to intervene at multiple stages of the production process as well as to the degree of ambiguity over what constitutes good management.

${ }^{76}$ The concern of accountability has been among the most recurrent problems concerning the involvement of private parties in rule-making. For an account of the US experience, see eg J Freeman, 'Private Parties, Public Functions and the New Administrative Law' in D Dyzenhaus (ed), Redrafting the Rule of Law (Oxford, Hart Publishing, 1999) 331ff.
} 


\section{Financial Regulation and Private Actors from a Citizen's Perspective: An Analysis Through the Lens of 'New Governance' Theory}

The involvement of private actors at different levels and, more specifically, the delegation of regulatory power to private regulators pose important questions concerning the accountability and liability of private regulators. An effective regulatory process thus requires that standard-setting obtains legitimacy from industry (financial institutions) and citizens. ${ }^{77}$ Legitimacy therefore conveys the notion of acceptability by the public (citizens).

Furthermore, such issues are to be contextualised within the sheer lack of confidence in the banking system. Regaining public trust is in fact one of the most topical subjects related to the regulation and supervision of financial undertakings. ${ }^{78}$ As empirical research shows, citizens' acceptance of any economic or social activity is directly correlated with the level of institutional trust and, therefore, the presence of the public character of regulatory governance as an institution underpinning the investment economy is necessary to facilitate acceptance of private investment risks and participation in the investment economy. ${ }^{79}$

In approaching such issues, this chapter will apply the tenets of 'new governance' theory. From a normative perspective, in the EU financial sector the private regulator acts on the basis of delegation or within regulatory power-sharing with a public entity. Therefore, purely private regulatory activity is absent, rather than rare.

This symbiotic relationship between 'external' and 'internal' regulation is premised on a clear articulation between regulators/supervisors and private actors. The former are called upon to set out rules that identify the regulatory outcomes (or desired behaviours) which they are designed to achieve (or incentivise), without prescribing the detailed procedures with which regulated actors are expected to comply. ${ }^{80}$ This is reflected in the presumption that regulated actors are better

\footnotetext{
${ }^{77}$ See F Cafaggi, A Coordinated Approach to Civil Liability and Regulation in European Law: Rethinking Institutional Complementarities' in F Cafaggi (ed), The Institutional Framework of European Private Law (Oxford, Oxford University Press, 2006) 191ff; S Whittaker, Liability for Products, English Law, French Law, and European Harmonisation (Oxford, Oxford University Press, 2005) 204; and S Weatherill, EU Consumer Law and Policy (Cheltenham, Edward Elgar, 2005) 199ff.

${ }^{78}$ See eg Group of Thirty, 'Banking Conduct and Culture: A Call for Sustained and Comprehensive Reform' (July 2015); FSB, ‘Guidance on Supervisory Interaction with Financial Institutions on Risk Culture' (April 2014).

${ }^{79} \mathrm{NC}$ Bronfman, EL Vázquez and G Dorantes, 'An Empirical Study for the Direct and Indirect Links Between Trust in Regulatory Institutions and Acceptability of Hazards' (2009) 47 Safety Science 686.

80 'Effective compliance will evolve away from a primary focus on the designing, implementing and monitoring processes that embed detailed regulatory rules in business operations. Instead, it will increasingly require the exercise of judgment': FSA, 'Principles-Based Regulation: Focusing on Outcomes that Matter' (April 2007) and J Black, M Hopper and C Band, 'Making a Success of Principles Based Regulation' (2007) 1 Law and Financial Markets Review 193.
} 
positioned and informed than regulators to determine the technological content of the policies and procedures necessary to achieve desired regulatory outcomes. ${ }^{81}$

For instance, each financial institution is required to set up and maintain 'the governance arrangements that ensure effective and prudent management of an institution, including the segregation of duties in the organisation and the prevention of conflicts of interest' (Article 88, Directive 2013/36/EU). This means that primary responsibility for internal governance rests upon market participants, since financial institutions are delegated to develop internal governance arrangements. However, internal governance arrangements are to be designed so as to pursue regulatory objectives that are beyond the mere private interests of the company (ie making profits). In fact, corporate governance serves a function in the overall financial regulation agenda, in that it secures the attainment of financial regulatory objectives (consumer protection, financial stability, etc).

More generally, financial regulation seems to possess the defining characteristics of the new governance theory. It often contemplates: (i) retention of a public role in law-making and enforcement; (ii) active pursuit of private actors' knowledge as a supplement; and (iii) a dynamic, flexible and dialogic law-making process (increased participation of, and power sharing with, private actors).

Most of the financial regulatory regime is the result of a conversational and dynamic interaction, whereby private involvement is analytically framed so as to achieve regulatory objectives. Such regulatory design is an expression of the fundamental rights of property and of freedom of enterprise (eg in the case of corporate governance, IRB, and recovery and resolution planning). Such freedom of enterprise seems to bring up a new host of regulatory challenges, as pointed out in the recent Grand Chamber judgment of the ECJ in Tadej Kotnick. ${ }^{82}$ Yet, the leeway attributed to the banks in expressing their self-regulatory power must nonetheless comply with the instructions, guidelines and information provided by the supervisors and regulators. The retention of public authority is therefore relevant and formally confined to prompting financial institutions to revise their choices insofar as the regulatory objectives so require. The self-regulatory measures are meant to be, and remain, private initiatives, yet under the 'benign gun threat' that supervisors can step into the material and substantive internal regulation which a firm has adopted.

However, ex post intensive supervision and vigorous enforcement are essential components of this regulatory strategy too. Not only is public authority to

\footnotetext{
${ }^{81}$ As explained by C Briault, 'Making a Real Difference to Consumers Through More Principles-Based Regulation', FSA, Treating Customers Fairly Conference (7 December 2006), the FSA's principles-based approach involves 'a shift of emphasis ... away from looking at the processes carried out by firms, toward the outcomes we seek to achieve for consumers, firms and markets'.

${ }^{82}$ See C-526/14, Judgment of 19 July 2016. Despite the fact that the case is about resolution measures (instead of recovery measures) adopted by a national competent authority before the implementation of the Bank Recovery and Resolution Directive, the ECJ discussed the tension between property rights and freedom of enterprise and public interests based on grounds of soundness and stability of the financial market.
} 
be retained ex ante, it is needed to identify and punish those un-cooperative credit institutions whose wilful misconduct would otherwise threaten to erode the mutual trust upon which 'new governance' theory is premised. ${ }^{83}$ For instance, in cases where competent authorities detect deficiencies in or impediments to the implementation of a recovery plan, or resolution authorities find that there are substantive impediments to the resolvability of the institution, the authorities are empowered to (re)direct the institution to implement a series of measures to facilitate the implementation of the recovery plan, or the resolvability of the institution, eg a reduction of the risk profile, recapitalisation, review of the strategy and structure, changes in the funding strategy, or the governance structure (Article 6, Bank Recovery and Resolution Directive). ${ }^{84}$

The supervisory practices therefore have to be characterised both by

a high frequency of interactions and high levels of expertise and independence on the part of supervisors [which] facilitates greater information flow between regulators and regulated actors and provides a built-in feedback mechanism for communicating regulatory expectations in a non-public, non-adversarial fashion. ${ }^{85}$

Insofar as financial regulation contemplates the devolution of responsibility for the generation of internal models and plans to deal with the proper viability of a bank, intensive supervision and the credible threat of enforcement are necessary in order to ensure the greatest possible congruence between private incentives and public regulatory objectives. ${ }^{86}$

As stated from the outset, in fact private actors are co-opted to cooperate and this dialogic interaction should not be mistaken for a complete devolution of self-regulatory powers to supervised entities. The retention of a significant public role for supervision and enforcement also serves to distinguish this regulatory approach from forms of unconstrained self-regulation (along with light-touch supervisory practices), which were popular in the pre-crisis era. ${ }^{87}$

Increased participation and power-sharing allow for structuring collaborative solutions to complex market imperfections. Recovery and resolution planning, for

\footnotetext{
${ }^{83}$ C Ford, 'New Governance, Compliance, and Principles-Based Securities Regulation' (2008) 45 American Business Law Journal 1, 10.

${ }^{84}$ More controversially in terms of intrusive new supervisory powers, to facilitate resolvability resolution authorities can dictate measures that include the revision of intragroup financing, or service agreements to cover the provision of critical functions, limits to individual and aggregate exposures, information requirements, orders to limit or cease specific activities, business lines or products, changes in operational structures to segregate critical functions, changes in corporate structure (eg the setting up for a parent holding company, or a separate holding company for the banking business within a conglomerate), or the issuance of liabilities eligible for bail-in.

${ }^{85}$ See Awrey (n 1) 273-315.

${ }^{86} \mathrm{~J}$ Black, 'Forms and Paradoxes of Principles-Based Regulation' (2008) 3(4) Capital Markets Law Journal 425; I Ayres and J Braithwaite, Responsive Regulation: Transcending the Deregulation Debate (Oxford, Oxford University Press, 1992).

${ }^{87}$ Expert Panel on Securities Regulation, 'Creating an Advantage in Global Capital Markets: Final Report and Recommendations’ (Canada, January 2009).
} 
instance, aim at correcting mainly three types of market failures: (i) the bounded rationality problem, since it forces the firm's managers to think through and more clearly confront the reality of the firm's possible failure; (ii) agency failure and information failure, because it indirectly motivates the firm's managers to consider how they can better govern the firm to avoid liquidation; and (iii) responsibility failure (or moral hazard) by motivating firms to operate responsibly without reliance on the corporate reorganisation protections of bankruptcy law.

Advantages to this regulatory approach include a reduced likelihood that supervisors and supervised entities will not be prepared to deal with economic and financial pathologies. Recovery and resolution planning not only aims at preventing crises from happening, but also at shoring up the system should a crisis materialise. ${ }^{88}$ The consequence is that systemically important firms should be less likely to fail and, if they do fail, should be less likely to externalise systemic costs.

Despite private actors' engagement being beneficial in overcoming the expertise gap, such collaboration might in fact introduce the risk of regulatory capture. ${ }^{89}$ More precisely, capture may be caused subtly through the provision of information, or so-called 'information capture'. The information imbalance between regulators and private actors, and the consequent dependency of the former on the latter, empowers industry to influence rules and standards, and tilts the outcome towards industry interests. Thus, as policy becomes more complex, and regulators become more dependent on industry, there is a higher likelihood that rules will be biased towards industry preferences. ${ }^{90}$ 'Representational capture' occurs when there is an imbalance in the representation of the competing interests, such as between commercial and public interests. In such cases, a regulator is at higher risk of adopting an industry-friendly point of view if the only people that it hears from, or primarily hears from, are industry members. ${ }^{91}$

The risk of regulatory capture seems to be also adequately managed by the threat of a 'benign gun'. In fact, information capture or representational capture are both confined by the retention of a public role in law-making and law enforcement. In that respect, industry involvement cannot justifiably lead to rules that prioritise private gains over the 'global' public interest. To the extent that regulators allow private actors to pitch in along the trajectory of well-identified regulatory objectives, the risk of capture seems materially unappreciable.

\footnotetext{
${ }^{88}$ On the concept of 'resilience, see, for example, the recent document released by the Financial Stability Board, 'Resilience Through Resolvability - Moving from Policy Design to Implementation. 5th Report to the G20 on Progress in Resolution' (18 August 2016).

${ }^{89}$ G Stigler, 'The Theory of Economic Regulation' (1971) 3 Bell Journal of Economics and Management Science 21.

${ }^{90} \mathrm{D}$ Carpenter and DA Moss, 'New Conceptions of Capture - Mechanisms and Outcomes' in D Carpenter and DA Moss (eds), Preventing Regulatory Capture: Special Interest Influence and How to Limit It (New York, Cambridge University Press, 2013); N McCarty, 'Complexity, Capacity, and Capture' in Carpenter and Moss, ibid, 102.

${ }^{91}$ SA Shapiro, 'Testimony before the Subcommittee on Administrative Oversight and the Courts of the Senate Committee on the Judiciary; Hearing on Protecting the Public Interest: Understanding the Threat of Agency Capture' (2010) 4.
} 


\section{Concluding Remarks}

The trajectory of financial regulation is very much based on cooperative modes of interaction between private and public actors. 'New governance' theory and scholarship posits that such cooperation between 'regulators' and 'regulated entities' is indeed essential to cope with the dynamism of modern financial intermediation. Internal ratings, internal governance measures, and recovery and resolution planning can be considered, in certain aspects, to be a 'new governance' technique. Private actors' involvement aims at overcoming market failures which would not have been remedied solely by traditional 'top-down' regulatory strategies. Nonetheless, from a citizen's perspective such strategies bring to the fore questions relating to legitimacy and accountability. In line with 'new governance' theory, the financial regulatory framework possesses the main characteristics for a publicprivate form of cooperation to work, namely: (i) retention of a public role in law-making and law enforcement; (ii) active pursuit of private actors' knowledge as a supplement; and (iii) a dynamic, flexible and dialogic law-making process (increased participation of, and power sharing with, private actors).

This requires regulators to define the main regulatory objectives, to articulate the rules on a flexible and dynamic basis, to accept input from the ground level of regulated entities, and to effectively manage incoming information from industry actors.

Greater interaction between regulators/supervisors and regulated entities seems to have several advantages over conventional 'top-down' regulation that are worth exploring further. By setting out such a dialogic model of regulation, regulators and supervisors will possibly be able to improve their diagnosis of sources of market dysfunction and deepen their understanding of complexity, market dynamics and business practices. By letting private actors pitch in, public actors are incorporating regulated institutions' internal models, thus bridging intractable information asymmetries resulting from the complexity and dynamism of contemporary financial institutions. 